\title{
Alkaloid Distribution in Seeds of Argemone mexicana L. (Papaveraceae)
}

\author{
Lloyd JA Loza-Muller, José Ignacio Laines-Hidalgo, Miriam Monforte-González, Felipe Vázquez- \\ Flota*
}

Unidad de Bioquímica y Biología Molecular de Plantas, Centro de Investigación Científica de Yucatán, Calle 43, No. 130 Chuburná 97205 Mérida Yucatán México.

*Corresponding author: Felipe Vázquez Flota, email: felipe@cicy.mx; Phone number: (52) 999-942-8330 (151).

Received April 29 $9^{\text {th }}, 2021$; Accepted June $1^{\text {st }}, 2021$.

\section{DOI: http://dx.doi.org/10.29356/jmcs.v65i4.1574}

\begin{abstract}
Seeds of Argemone mexicana L. accumulate significative amounts of sanguinarine. The analysis of the distribution of this alkaloid through the tissues of mature seeds revealed that up to $60 \%$ of its contents was found tightly fixed to the different components of the seed external covers where it persisted during seedling germination. Contrastingly, sanguinarine contents in cotyledon accounted for the remaining $40 \%$ and it could have been, at least partially, mobilized to the newly formed hypocotyls during emergence from seeds. Berberine was only detected in immature seeds and in seedlings once cotyledons were totally displayed. These results are discussed as a possible sanguinarine role in the chemical protection during seedlings germination.
\end{abstract}

Keywords: Argemone mexicana; berberine; sanguinarine; seeds.

Resumen. Semillas de Argemone mexicana L. acumulan cantidades elevadas de sanguinarina. Un análisis de la distribución de alcaloides en los diferentes tejidos que componen la semilla reveló que hasta un $60 \%$ del contenido se encontraba fuertemente unido en las capas que forman la cubierta exterior, donde se retuvieron durante la emergencia del hipocótilo. En contraste, los cotiledones presentaron el $40 \%$ restante y parte de ello pudo haber sido movilizado al hipocótilo al emerger. Berberina sólo se observó en semillas inmaduras y en plántulas en desarrollo con los cotiledones desplegados. Estos resultados se discuten en función del posible papel defensivo de la sanguinarina durante la germinación.

Palabras clave: Argemone mexicana; berberina; sanguinarina; semillas.

\section{Introduction}

Alkaloids are toxic nitrogenous compounds providing chemical defense to the organism that produce them [1]. In plants, alkaloids are often accumulated in tissues susceptible to be assaulted by predators, such as sprouts, or reproductive structures, i.e., flowers and seeds, because their high protein and sugar contents. Although protective during early stages of germination, the presence of toxic chemicals in seed and seed holding organs plays an important role in spreading of the population, since it could restrict it to the participation of specialist herbivores or to environmental conditions [2]. Presence of alkaloids in fertilized tissues, such as fruits and seeds, occurs through different plant families. Since seeds function as sink organs importing sugars and other metabolites through direct vascular connections, the origin of the alkaloids found in them could be traced to other parts of the fruit or distant tissues [3]. In Datura stramonium (Solanaceae), the tropane alkaloids 
atropine and scopolamine accumulate in both pericarps and seeds, whereas scopolamine is only found in seeds, where no biosynthetic activity has been observed [4]. In Coffea (Rubiaceae), purine alkaloids are produced in mesocarps, but accumulated in seeds [5]. In Papaver somniferum (Papaveraceae), the benzylisoquinoline alkaloid morphine is found in the capsular fruits but not in seeds, which seems related to the absence of laticifer cells where the alkaloid is accumulated [6]. Argemone mexicana L., the Mexican prickly poppy, is another member of the Papaveraceae family which accumulates berberine throughout the complete plant, except in mature seeds, and sanguinarine exclusively in roots and seeds even when biosynthetic activity could be detected in stems and leaves [7,8]. Argemone seeds are contained in septicidal capsules with four to six locules. Inside the capsules, seeds remain attached to the intralocular septum by the placenta [9]. During development and desiccation, the seed testa engrosses and turns from transparent to yellow-brownish and black with the appearance of concave depressions on the surface which confer it a reticulate aspect. At mature stage, Argemone seeds are small (ca. $1 \mathrm{~mm}$ diameter) and spherical shaped (Fig. 1). An external cuticle covers the episperma consisting of a thick testa, formed by three cell layers and the internal tegmen, which involves the endosperm [9].

Interestingly, the newly displayed cotyledons of unfolding seedlings lack of sanguinarine whereas high contents could be still found in the detached seed coats [8]. Recently, evidence of a possible alkaloid protein transporter operating in seeds has been reported [10]. Therefore, the precise location of sanguinarine in seeds would help to integrate a better model about the role of this alkaloid during seed germination and seedling establishment.
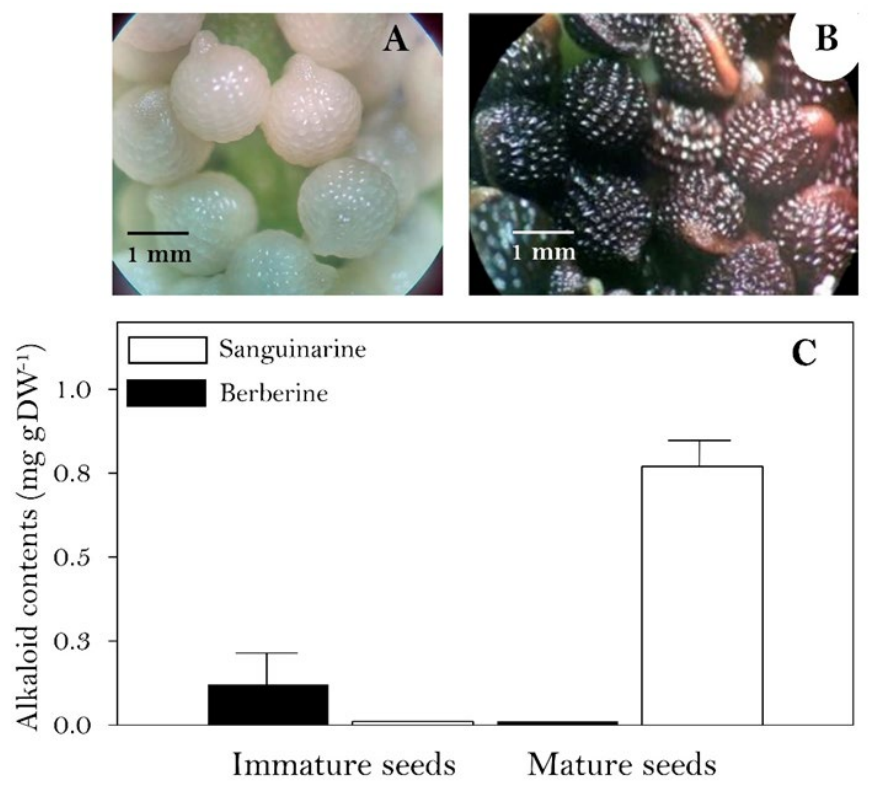

Fig. 1. Alkaloids contents A. mexicana seeds at different developmental stages. Aspect of the immature (A) and mature (B) seeds. Berberine (full bars) and sanguinarine (empty bars) contents (C). Average of three repetition with standard deviation.

\section{Experimental}

Plant materials. Immature and mature seeds were collected from 10- and 18-day post anthesis (DPA) indehiscent and dehiscent capsules, respectively. Indehiscent fruits were cut opened with a scalpel to harvest the seeds. For alkaloid distribution in seed tissues, 80 seeds $(95 \mathrm{mg}$, i.e., $1.19 \mathrm{mg}$ per individual seed) were mechanically separated in external cuticle, testa, internal tegmen and endosperm with tweezers and flat rounded end spatulas (see Fig. 2(A)). Each tissue component was individually collected in microcentrifuge tubes and weighted to estimate their contribution to seed biomass. Alkaloid contents were estimated both on dry matter 
as per single seed (Fig. 2(C)). For germination, seeds were manually scarified with sandpaper and then placed on top of wet filter contained in Petri dishes. Alkaloids were washed out from 100 seeds incubating them in water, $100 \mathrm{mM}$ phosphate buffer at $\mathrm{pH} 5,7,8$ and 10 , methanol or $10 \% \mathrm{NH}_{4} \mathrm{OH}$ during 1, 3, 12 and $24 \mathrm{~h}$, with gentle agitation. Alkaloid from the aqueous solvents were recovered as described lines below increasing $\mathrm{pH}>$ 10 with $\mathrm{NH}_{4} \mathrm{OH}$.

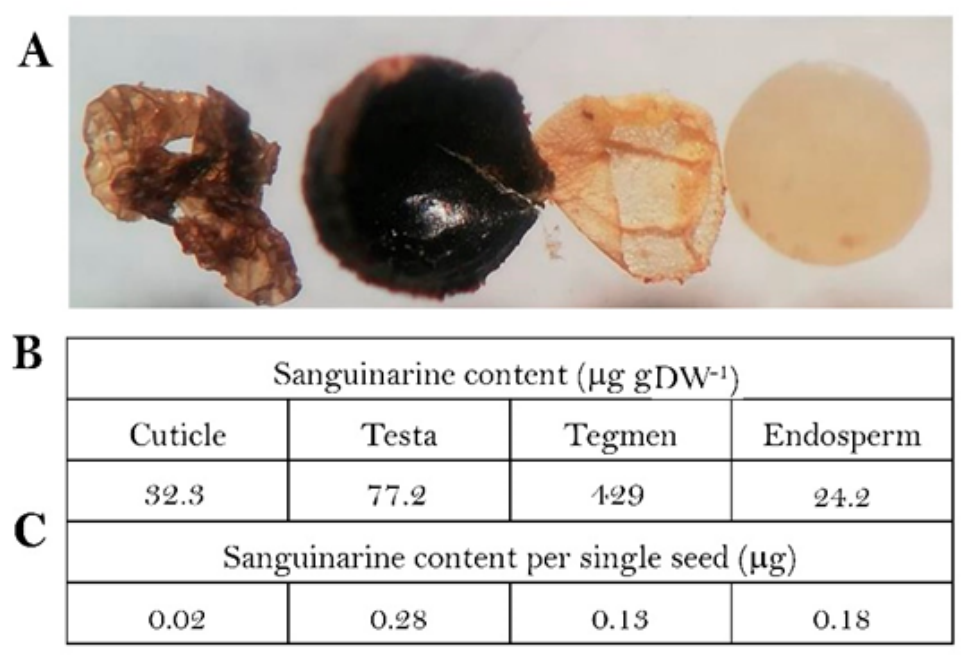

Fig. 2. Sanguinarine distribution in the different seed tissue components. (A) aspect of the external cuticle, testa, tegmen and endosperm (left to right) of mature seeds. Sanguinarine contents on dry weight basis (B) and per single seed (C). Alkaloid per seed was estimated from the total contents of an 80 seed batch. Individual weight of seed tissues was estimated dissecting 80 units and dividing the total for that number. Values in (B) are average of triplicates (standard deviation was less than $15 \%$ in all cases).

Alkaloid analysis. Alkaloids were extracted from ground tissues in $1.0 \mathrm{~mL}$ of methanol, as described in [11]. Extracts were separated by TLC, using a mixture of n-butanol: water: $\mathrm{NH}_{4} \mathrm{OH}(8: 1: 1)$ and benzene: ethanol (9:1) for berberine ( $\operatorname{Rf} 0.29$ ) and sanguinarine ( $\mathrm{Rf} 0.53$ ), respectively. After chromatographic separation, alkaloids were quantified by in situ fluorescence, using a Camag TLC Scanner 4 (Muttenz Switzerland) controlled by the WinCATS 1.4 .10 planar chromatography manager [11]. When required, alkaloids were retrieved from aqueous solutions increasing $\mathrm{pH}>10$ with $\mathrm{NH}_{4} \mathrm{OH}$ and extracting with equals volumes of EtOAc [12]. Identity of the chromatographic bands has been previously established by LC-MS $[8,12]$.

\section{Results}

Immature seeds from capsules 10 DPA were near final dimensions, friable and with a thin, transparent episperma. Humidity content was near $85 \%$ (Fig. 1(A)). Upon desiccation, water content decreased to less than $10 \%$ and the episperma (testa and tegmen) turned black, showing the typical reticulate aspect (Fig. 1(B)). Low amounts of berberine, but not sanguinarine were detected in the immature seeds, whereas in mature seeds, high amounts of sanguinarine ( $c a .0 .8 \mathrm{mg} \mathrm{gDW}^{-1}$ ) were observed (Fig. 1(C)). These values are among the usually reported 0.6 and $1.0 \mathrm{mg} \mathrm{gDW}^{-1}$ ) for Argemone seeds [7]. Since no berberine was observed, it was not further monitored in the mature seeds.

Mature seeds were dissected in cuticle, testa, tegmen and endosperm (Fig. 2(A)) and sanguinarine content was analysed (Fig. 2(B)). On dry weight basis, tegmen showed the highest contents (429 mg gDW-1) 
followed by the testa $\left(77.2 \mathrm{mg} \mathrm{gDW}^{-1}\right)$, and with the external cuticle and endosperm presenting the lowest contents (32.3 and $24.2 \mathrm{mg} \mathrm{gDW}^{-1}$; Fig. 2(B)).

Considering the registered weights, in this experiment sanguinarine content was estimated as $0.67 \mathrm{mg}$ per seed (563 mg sanguinarine per g of seeds; $1.19 \mathrm{mg}$ each seed). Since cuticle, tegmen and testa represent 5 , 2.5 and $30 \%(0.06,0.03$ and $0.35 \mathrm{mg})$ of the individual seed weight, respectively, seed external layers (cuticle and episperma) contributed with over $65 \%$ of the total sanguinarine contents $(0.43 \mathrm{mg}$ per seed; adding values from each tissue, Fig. 2(C)) even when together represented less than $40 \%$ of the total mass.

Sanguinarine displays antimicrobial properties [13] and its location in the external seed layers suggest a role in seedling protection during germination and establishment [13]. Hence, seeds were incubated in different solvents to observe if they were either retained in the seed coat or released to the surroundings. Due to the differential solubility of alkaloids in acidic and alkaline media, buffer solutions were assayed as well as plain water, $\mathrm{NH}_{4} \mathrm{OH}$ and methanol (Fig. 3). Under the conditions, none of the aqueous solvents succeed in washing the alkaloid out suggesting a firm attachment to the matrix, or its reduced permeability to the coats.

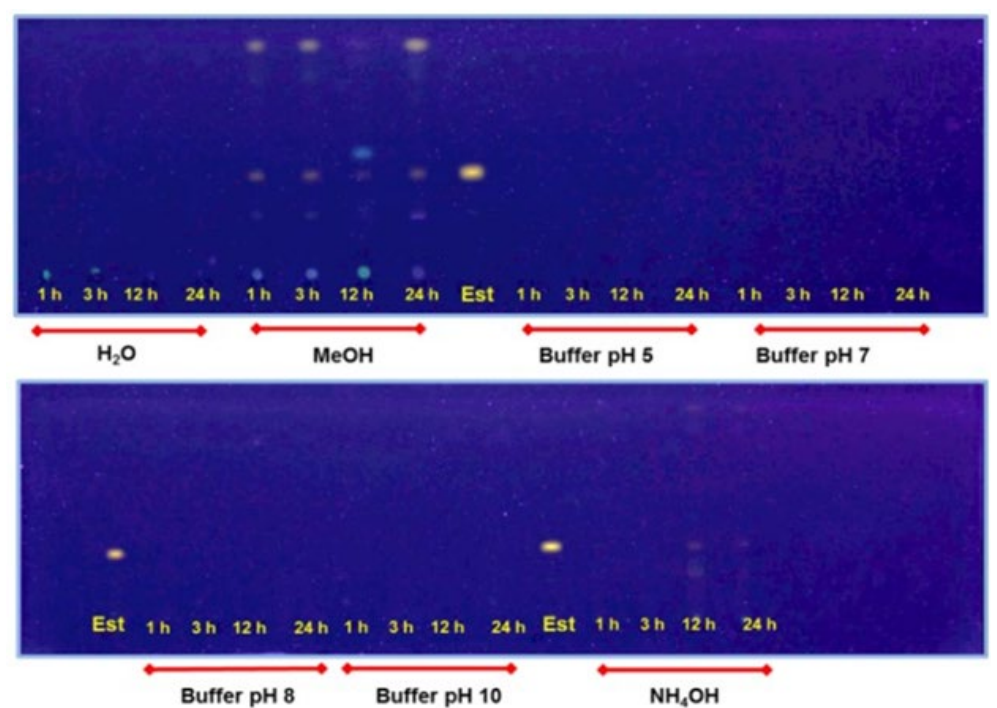

Fig. 3. Sanguinarine retrieved from seed wash outs with methanol (MeOH), and $100 \mathrm{mM}$ phosphate buffer at pH 5 and 7 (upper panel), 8, 10, and $\mathrm{NH}_{4} \mathrm{OH} 10 \%$ (lower panel). 100 seeds were incubated with agitation in $50 \mathrm{~mL}$ of the solutions for the times indicated. Est, sanguinarine standard at $R f 0.53$ (benzene: ethanol 9:1). Detection limit at $5 \mathrm{ng}$ [11].

Although these observations point to a possible sanguinarine role in the chemical defense of the actual seed structures, rather than to the soil adverse microflora during seedling unfolding, liberation of sanguinarine has been observed from Argemone radicles tips during this process [7]. Hence, alkaloid contents were analysed at the early stages of hypocotyl emergence (Fig. 4). Sanguinarine, was noticed in the hypocotyl, coinciding with a slight decrease in cotyledon contents whereas those of the complete coat remained in similar levels, indicating the possible mobilization from cotyledons to this newly formed organ (Fig. 4(A)). In totally unfolded seedlings (Fig. 4(B)), low sanguinarine levels was observed in the displayed cotyledons whereas radicles presented similar contents to those previously reported $\left(c a .0 .8 \mathrm{mg} \mathrm{gDW}^{-1}\right)$ [7]. Interestingly, berberine was now detected in these organs [7]. However, some released sanguinarine could be detected in radicle surrounding areas [7]. 


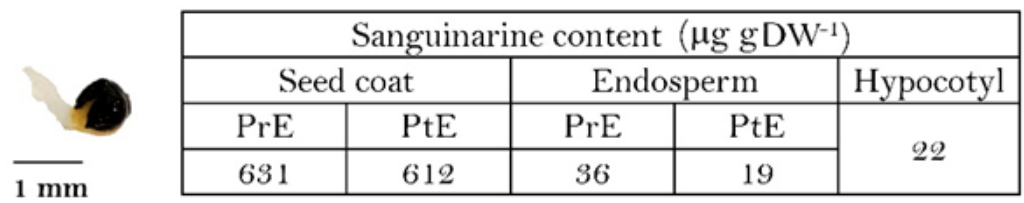

\begin{tabular}{|c|c|c|}
\hline \multirow{2}{*}{ Alkaloid } & Cotyledons & Hypocotyls \\
\hline & \multicolumn{2}{|c|}{$\mu \mathrm{g} \mathrm{gDW}^{-1}$} \\
\hline Sanguinarine & 47 & 368 \\
\hline Berberine & 614 & 412 \\
\hline
\end{tabular}

Fig. 4. Alkaloid contents during A. mexicana seed germination at the hypocotyl (A) and seedling (B) stages. PrE and PtE, prior- and post-hypocotyl emergence, respectively. Hypocotyls and seedlings were collected 12 and 18 days after planting. Average of triplicates, standard deviation was less than $15 \%$ in all cases.

\section{Discussion}

During seed germination and hypocotyl emergence, cell division rely on the stored reserves rather than on new biosynthetic processes [14]. Although in A. mexicana, an early alkaloid biosynthetic activity has been noticed [7], it occurred after cotyledon display [7], similarly, to has been observed in Catharanthus roseus for monoterpene indole alkaloids [15]. Hence, stored alkaloids might play a role in protecting the newly formed organs until they acquire the biosynthetic capacity required. Therefore, sanguinarine mobilization to emergent hypocotyl from the endosperm, as suggested in results in Fig. 4(A), could provide chemical defense to this organ whereas that remained in the seed coat would do it for cotyledons [7]. Interestingly, once seed coats were detached and cotyledons displayed, newly formed berberine seems to take that role in them whereas radicles keep important amounts of both alkaloids. Sanguinarine has been suggested to have certain functions, allelopathic among them [13]. In fact, it was detected around seedling radicles, supporting this interpretation (Fig. 4(B)). However, since sanguinarine from the external seed covers was not released at the conditions assayed (Fig. 3), results in here reported about sanguinarine distribution in A. mexicana seeds, seem consisting with a protective role of the developing structure, rather than eliminating harmful soil microflora.

\section{Acknowledgements}

This work was supported by the National Council of Science and Technology (CONACYT, México); grant CB-2016-0285887. LL-M and JILH are recipient of CONACYT scholarships for doctoral studies.

\section{References}

1. Zenk, M. H.; Juenger, M. Phytochemistry. 2016, 65, 2757-2772

2. Hartmann, T. Planta 2004, 219,1-4

3. Ziegler, J.; Facchini, P. J. Ann. Rev. Plant Biol. 2008, 59, 735-769.

4. Miraldi, E.; Masti, A.; Ferri, S.; Comparini, I. B. Fitoterapia. 2001, 72, 644-648.

5. Koshiro, Y.; Zheng, X. Q.; Wang, M. L.; Nagai, C.; Ashihara, H. Plant. Sci. 2006, 171, 242-250.

6. Weid, M.; Ziegler, J.; Kutchan, T. M. Proc. Natl. Acad. Sci. USA. 2004, 101, 57-62. 
7. Xool-Tamayo, J.F.; Monforte-González, M.; Rubio-Piña, J.; Mirón-López, G.; Vázquez-Flota, F. Phytochem. Lett. 2017, 20, 300-305.

8. Vázquez-Flota, F.; Rubio-Piña, J.; Xool-Tamayo, J.; Vergara-Olivares, M.; Tamayo-Ordoñez, Y.; Monforte-González, M.; Guízar-González, C.; Mirón-López, G. Rev Fitotec. Mex. 2018, 41, 13-21.

9. Cresson, R. A.; Schneider, E. L. Bull. Torrey Bot. Club. 1988, 108-112.

10. Loza-Muller, L.; Trujillo-Villanueva, K.; Vázquez-Flota, F. Book of abstracts XVIII National Plant Biochemistry and Molecular Biology Congress 2019, 163, 226.

11. Monforte-González, M.; Guízar-González, C.; Rubio-Piña, J.; Carrillo-Pech, M.; Vázquez-Flota, F. J. Planar Chromatogr. - Modern TLC. 2012, 25, 358-360.

12. Guízar-González, C.; Trujillo-Villanueva, K.; Monforte-González, M.; Vázquez-Flota, F. J. Mex. Chem. Soc. 2012, 56, 19-22.

13. Rubio-Piña, J.; Vázquez-Flota, F. Curr. Top. Med. Chem. 2013, 13, 2200-2207.

14. Harada, J. J. Plant Physiol. 2001, 158, 405-409.

15. Vázquez-Flota, F.; St-Pierre, B.; De Luca V. Phytochemistry. 2000, 55, 531-536. 